\title{
Geochemical and Petrographical Study of Megacrysts and Mantle Xenoliths from Gemsbok Hollow and Gruendorn Kimberlites in the Warmbad Kimberlite Province, South Africa.
}

\author{
de Klerk, W. ${ }^{1}$, Bell, D.R. ${ }^{1}$ \\ 1 Africa Earth Observatory Network - Earth Stewardship Science Research Institute (AEON-ESSRI), Nelson \\ Mandela Metropolitan University (NMMU), Port Elizabeth, South Africa, geologistwdk@gmail.com, \\ David.Bell@nmmu.ac.za

\section{Introduction} \\ Kimberlites and their inclusions are unique in their depth of origin, thereby providing insights to mantle \\ lithology and geochemistry. In Southern Africa, with it's anomalously high topography, kimberlites are \\ widely distributed across contrasting crustal tectonic terranes, offering the opportunity to compare the \\ composition of the deep lithosphere between these regions, as well as to examine processes of \\ kimberlite genesis. The aim of this study is to characterize the field relations, petrography and \\ geochemistry of two xenolith-bearing Warmbad kimberlites (Gemsbok Hollow (GBH) and Gruendorn \\ (GD)) with a focus on their mantle xenolith suites in order to improve our knowledge of the underlying \\ mantle in this region. In addition this study will further contribute to megacryst formation processes \\ and origin as well as provide further insights, in the context of megacryst analyses from GBH and GD \\ as well as $\sim 50$ other Southern African kimberlite suites, to characterize deep lithospheric structure and \\ compositional variation.
}

\section{Study Area}

The Warmbad kimberlite province is part of a larger province known as the Namaqua-BushmanlandWarmbad (NBW) kimberlite and melilitite province. This study focuses particularly on the Warmbad kimberlite province (WKP) which is a relatively unstudied group of $\sim 30$ kimberlite pipes (including the GBH and GD pipes in this study) and dikes that erupted through the Proterozoic Namaqua belt in Southern Namibia and the Northern Cape province of South Africa. The kimberlites in this region have erupted through a complex tectonostratigraphic Proterozoic Namaqua belt crustal tectonic terrane, the various domains (Richetersveld, Bushmanland, Kakamas, Areachap, Kaaien) within Proterozoic Namaqua belt amalgamated in Grenville Orogeny (1-1.3 Ga) (Bial et al., 2016; Hartnady et al., 1985). The Group I kimberlites of GBH $\left(-28.055200^{\circ} ; 20.037710^{\circ}\right)$ and GD $\left(-28.053350^{\circ} ; 20.029230^{\circ}\right)$ are situated approximately $100 \mathrm{~km} \mathrm{WNW}$ of Upington, South Africa, adjacent to the border between South Africa and Namibia (Figure 1). The dating of these kimberlites has proved somewhat difficult with some as old as $530 \mathrm{Ma}$ (perovskite, U-Pb, Ondermatjie) (Wu et al. 2010) and some as young as $60 \mathrm{Ma}$ e.g. Stolzenfels (perovskite U-Pb) (Griffin et al. 2014). Rietfontein for example has two age determinations that conflict, $72 \mathrm{Ma}$ (zircon, U-Pb) (Davis et al., 1976) and $134 \pm 9 \mathrm{Ma}$ (perovskite, U$\mathrm{Pb}$ ) (Griffin et al. 2014). 


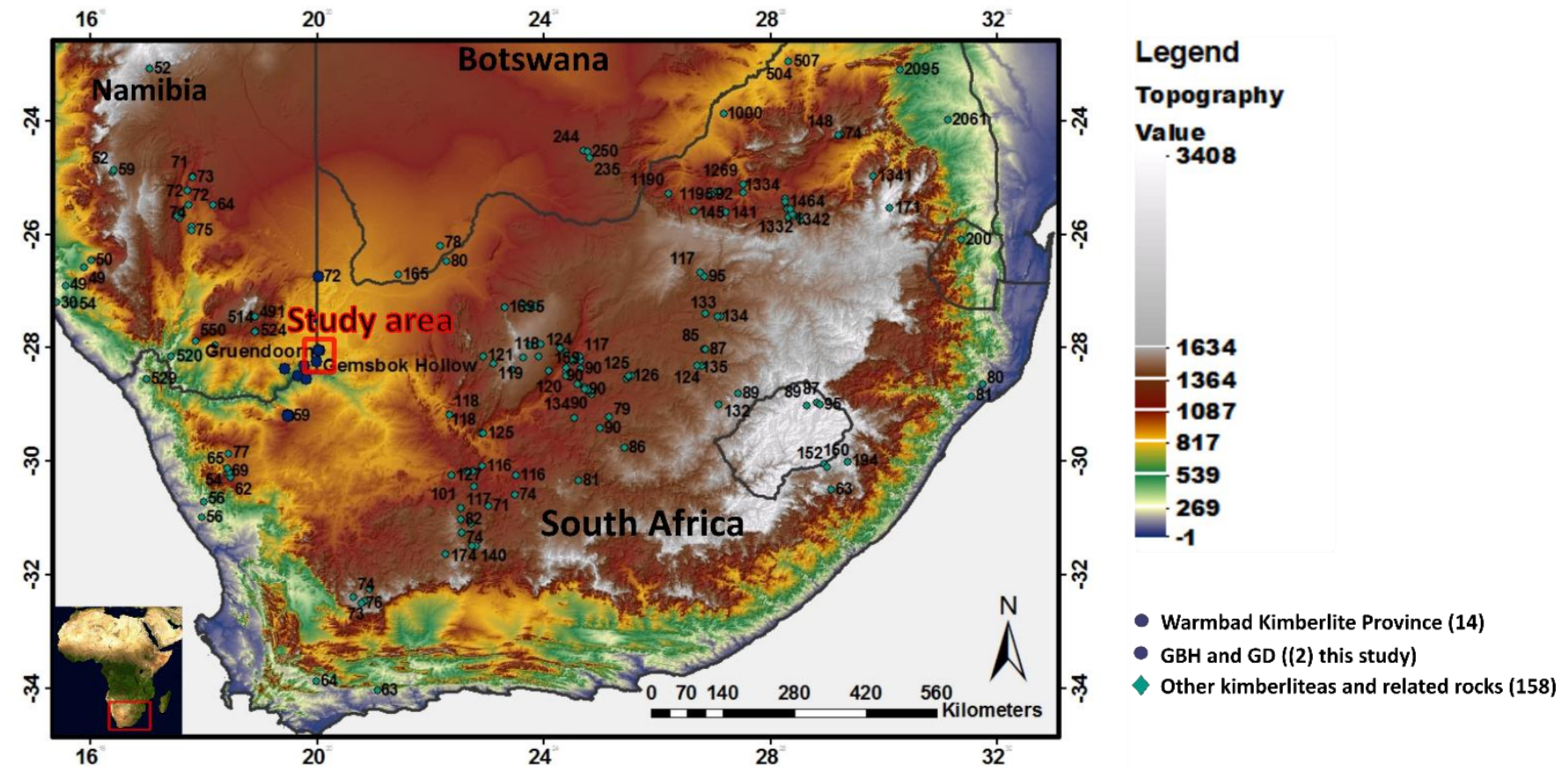

Figure 1: Regional topographic map showing kimberlite and related rock age distributions in relation to some Warmbad kimberlites (dark blue) in the study area (kimberlite data:Jelsma et al., 2009; this study). The few age constraints suggest a late-Cretaceous eruption age ( 75 Ma) with some evidence for a possible older ( 500 Ma) component for the Warmbad kimberlites of $G B H$ and $G D$.

\section{Samples and Preliminary Petrographic Results}

Reconnaissance field work has revealed two large pipes, approximately $70 \mathrm{~m}$ and $400 \mathrm{~m}$ in diameter, and associated sills capped by carbonate. These intrud into sediments of the Nama Group at the plateau forming the northern margin of the Orange River drainage system (Figure 2). Kimberlites in the Nama plateau typically present as dome-like depressions and often exhibit a blue to greenish colour depending on the degree of weathering.

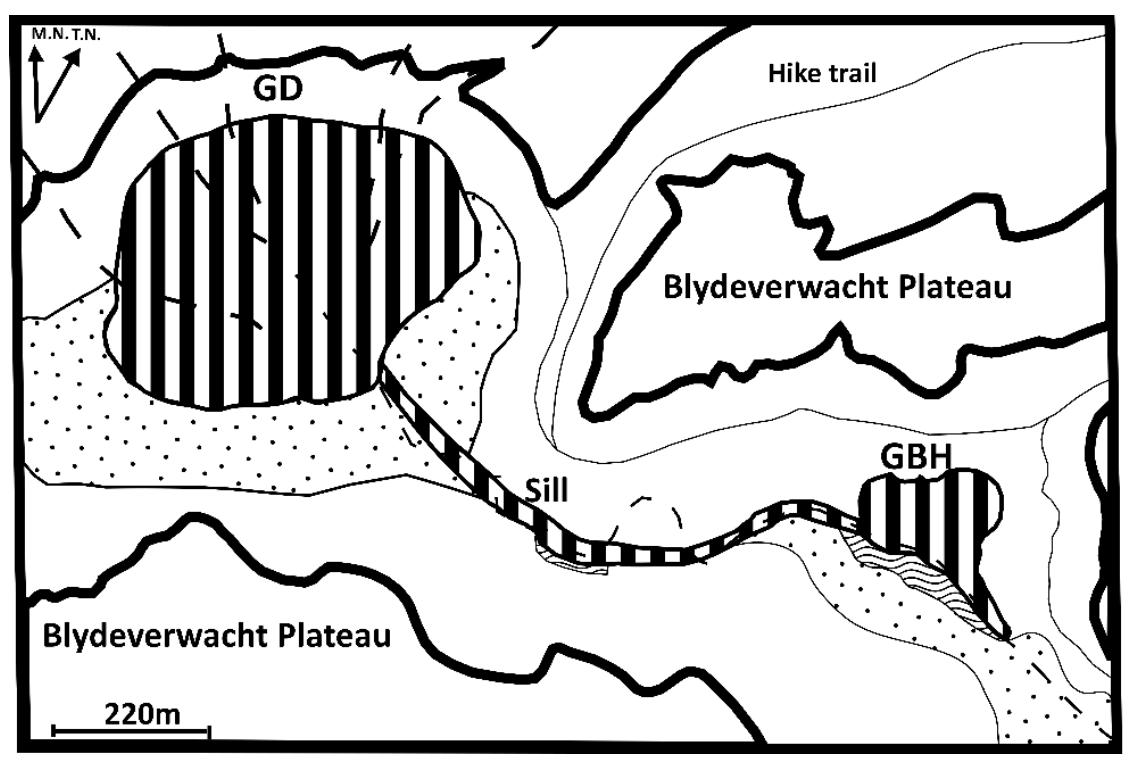

Legend

$\because \because$ Alluvium

氛 Calcrete

DI Kimberlite

Nama Group Rocks

Escarpment

- - River

Figure 2: Field sketch of the two diatremes of Gruendorn (GD) and Gemsbok Hollow (GBH) and associated sill that has intruded in the Pre-Cambrian-Cambrian aged Nama Group rocks at the plateau of the northern margin of the Orange River drainage system.

The mantle-derived inclusion suite consists of peridotites, Cr-poor megacrysts and occasional eclogite and pyroxenite. The megacryst suite is dominated by abundant garnet megacrysts $(\leq 6 \mathrm{~cm}$ in diameter), 
abundant ilmenite $(\leq 2 \mathrm{~cm})$, and rarer phlogopite, subcalcic clinopyroxene $(\leq 3 \mathrm{~cm})$ and zircon $(5-10$ $\mathrm{mm})$. Relative abundances of megacryst minerals differ at the two pipes. Several garnet megacrysts are deformed and a few contain inclusions of sub-rounded clinopyroxene and/or subrounded to amoeboidal shaped quenched sulfide melt pockets. Clinopyroxenes with garnet exsolution lamellae are also observed. Peridotites (up to $\sim 50 \mathrm{~cm}$ ) are highly weathered, with fresh olivine and/or orthopyroxene $(8 \%)$ rarely preserved, and are dominated by garnet lherzolite $(80 \%)$ with subordinate harzburgite $(10 \%)$ and dunite $(2 \%)$. The majority of peridotites have relic coarse granular textures with rounded garnet grains with extensive kelyphite rim development, whilst others have porphyroclastic texture. Preliminary micro-petrographic observations using SEM have revealed low Na content for the garnet megacryst suite, although secondary garnet patches or zones with relatively higher Na content $(\sim 2 \mathrm{wt} \%)$ have been observed in some garnets and seem to be a major coexisting phase inclusion with secondary cpx $(\sim 2 \mathrm{wt} \% \mathrm{Na})$ patches. In both these types of inclusion patches ilmenite is always present as an inclusion. In addition, large primary subrounded, isolated cpx inclusions are also observed. Some nonisolated cpx inclusions have vein-like extensions, suggesting possible introduction as a droplet. Quenched sulphide melt pockets were identified that are polyphased, traces of small sulphide droplets in an aligned row have been observed, suggesting the denser material percolated into partial crystalizing garnet, possibly crystalizing from a melt. Some of these garnets show single grains with differing $\mathrm{Ca}$ content, with zig-zag grain boundaries, indicating they were possibly amalgamated and fused together under subtle differing temparuture conditions, similarly for some cpx megacrysts. Some ilmenite zoning has been observed. Ilmenite megacrysts themselves do not have cpx inclusion, with dolomite (occurring as percolative droplets or as veins in which the dolomite is zoned), apatite and rutile being the major inclusion phases. Mica megacrsyts exhibit is a strong mineral inclusion association between xenotime and zircon, with zircons occurring as inclusions within the large xenotime crystals. In addition, there is also a spatial relationship between the occurrence of apatite and zircon as well as a spatial relationship between ilmenite, xenotime (Y-phosphate), zircon and apatite (Ca-phosphate). The major inclusion phase in the mica megacrysts are thus phosphates in association with zircon and apatite.

\section{Ongoing Work}

Numerous grains from various samples constituting 50 garnet megecrysts $(\mathrm{GBH}), 30$ garnet megacrysts (GD), 13 Cpx megacrysts (GBH, GD combined), 50 ilmenite megacrysts (50 ilmenite), mica megacryst (10), 30 peridotite garnets $(\mathrm{GBH}), 30$ peridotite cpx $(\mathrm{GBH})$ have been mounted for EPMA-WDS and LA-ICPMS analysis of major and trace - elements, with additional sample preparation for radiogenic isotope analysis. In addition, few zircon megacrysts, and few zircon inclusions in mica megacrysts are prepared in preperation for geochronology. These geochemical results, together with field relations and petrographic observations, wil be used to improve our knowledge of the underlying mantle, megacryst petrogenesis and lithospheric structure in the region. Additionally, these results together with $~ 50$ other Southern African kimberlite suites, will be used to characterize deep lithospheric structure and compositional variation over crustal tectonic terranes.

\section{References}

Bial J, Büttner S, Appel P (2016) Journal of African Earth Sciences Timing and conditions of regional metamorphism and crustal shearing in the granulite facies basement of south Namibia: Implications for the crustal evolution of the Namaqualand metamorphic basement in the Mesoproterozoic. J African Earth Sci 123:145-176.

Davis, G.L., Krogh, T.E., Erlank AJ (1976) The ages of zircons from kimberlites from South Africa. In: Year Book-Carnegie Institution of Washington, Vol. 75. pp 821-824

Griffin WL, Batumike JM, Greau Y, et al (2014) Emplacement ages and sources of kimberlites and related rocks in southern Africa: $\mathrm{U}-\mathrm{Pb}$ ages and $\mathrm{Sr}-\mathrm{Nd}$ isotopes of groundmass perovskite. Contrib to Mineral Petrol 168:1-13.

Hartnady C, Joubert P, Stowe C (1985) Proterozoic crustal evolution in southwestern Africa. Episodes 8:236-244.

Jelsma H, Barnett W, Richards S, Lister G (2009) Tectonic setting of kimberlites. Lithos 112:155-165. Wu FY, Yang YH, Mitchell RH, et al (2010) In situ U-Pb age determination and Nd isotopic analysis of perovskites from kimberlites in southern Africa and Somerset Island, Canada. Lithos 115:205-222. 